\title{
IMPLEMENTASI FUNGSI SATUAN POLISI PAMONG PRAJA DI KABUPATEN GRESIK
}

\author{
Darmawan \\ darmawan-2016@pasca.unair.ac.id \\ Pemerintah Kabupaten Gresik \\ Jln. Dr. Wahidin Sudirohusodo No. 245, Kembangan, Gresik Regency
}

\begin{abstract}
In the implementation of the Regional Government, Civil Service Police Unit (later called Satpol PP) has a trategic role related to the implementation of the obligations of regional government. Generally, Satpol PP has three function are : 1) Implementation of Public Peace and Order; 2) Enforcement of Regional Regulations; and 3) Community Protection. On the basis of the implementation of their duties, the Satpol PP has a formative foundation to establish Law Number 23 of 2014 concerning Regional Government; Government Regulation Number 16 of 2018 concerning Satpol PP; Minister of Home Affairs Regulation Number 54 of 2011 concerning Satpol PP Operating Standards, as well as regional regulations related to implementation technical tasks in each field. The implementation of duties in enforcement of regional regulations area, Satpol PP carried out activities such as first to provided guidance to the community and legal entities that violated regional regulations; second they conducted non-judicial control ; third they did enforce the law regarding the judiciary and the last are to supervise violation. Enforcing local regulations done by Satpol PP in Gresik Regency is carried out through pre-emptive, preventive, persuasive and represive approaches to the community without selective objectives with the aim of achieving the Regent's vision and mission and to increase the locally- generated revenue.
\end{abstract}

Keywords: Civil Service Police Unit, Regional Government and non-judicial control

\begin{abstract}
Abstrak
Dalam pelaksanaan Pemerintah Daerah, Satuan Polisi Pamong Praja (kemudian disebut Satpol PP) memiliki peran strategis terkait dengan pelaksanaan kewajiban pemerintah daerah. Secara umum, Satpol PP memiliki tiga fungsi yaitu: 1) Implementasi Ketertiban dan Ketertiban Umum; 2) Penegakan Peraturan Daerah; dan 3) Perlindungan Masyarakat. Atas dasar pelaksanaan tugasnya, Satpol PP memiliki landasan formatif untuk menetapkan Undang-Undang Nomor 23 Tahun 2014 tentang Pemerintah Daerah; Peraturan Pemerintah Nomor 16 Tahun 2018 tentang Satpol PP; Peraturan Menteri Dalam Negeri Nomor 54 Tahun 2011 tentang Standar Operasional Satpol PP, serta peraturan daerah terkait dengan pelaksanaan tugas teknis di masing-masing bidang. Pelaksanaan tugas dalam penegakan peraturan daerah, Satpol PP melakukan kegiatan seperti pertama memberikan pedoman kepada masyarakat dan badan hukum yang melanggar peraturan daerah; kedua mereka melakukan kontrol non-yudisial; ketiga mereka menegakkan hukum tentang peradilan dan yang terakhir adalah mengawasi pelanggaran. Menegakkan peraturan daerah yang dilakukan oleh Satpol PP di Kabupaten Gresik dilakukan melalui pendekatan pre-emptive, preventif, persuasif dan representatif kepada masyarakat tanpa tujuan selektif dengan tujuan mencapai visi dan misi Bupati dan untuk meningkatkan pendapatan yang dihasilkan secara lokal.
\end{abstract}

Kata Kunci: Polisi Pamong Praja, Pemerintahan Daerah dan control non-yudisial. 


\section{A. Pendahuluan}

Era desentralisasi Pemerintahan pada pemerintah daerah membuat peran Satuan Polisi Pamong Praja (Satpol PP) sangat strategis dalam pelaksanaan urusan wajib pemerintahan daerah. Sesuai dengan Pasal 255 Undang-Undang Nomor 23 Tahun 2014 dibentuk dalam rangka (1) Penyelenggaraan ketentraman dan ketertiban umum (Trantibum); (2) Penegakan perda dan; (3) Perlindungan masyarakat (Linmas). Fungsi utama penyelenggaraan trantibum ini adalah urusan wajib pemerintah daerah yang tidak dapat diwakilkan sebagaimana pembagian urusan pemerintahannya.

Pamong Praja berasal dari kata Pamong dan Praja, Pamong artinya pengasuh yang berasal dari kata Among yang juga mempunyai arti sendiri yaitu mengasuh. Mengasuh anak kecil misalnya itu biasanya dinamakan mengemong anak kecil, sedangkan Praja adalah pegawai negeri. Pangreh Praja atau Pegawai Pemerintahan. Menurut Kamus Besar Bahasa Indonesia Pamong Praja adalah Pegawai Negeri yang mengurus pemerintahan Negara. Definisi lain Polisi adalah Badan Pemerintah yang bertugas memelihara keamanan dan ketertiban umum atau pegawai Negara yang bertugas menjaga keamanan. Berdasarkan definisi tersebut diatas dapat disimpulkan bahwa Polisi Pamong Praja adalah Polisi yang mengawasi dan mengamankan keputusan pemerintah di wilayah kerjanya ${ }^{1}$ Dalam hal penegakan perda dan penyelenggaraan trantibum, Satpol PP dapat melakukan penindakan melalui tahapan-tahapan sesuai dengan Standar Operasional Prosedurnya baik secara Yustisial dan Non Yustisial. Di Kabupaten Gresik, terdapat empat peratauran daerah yang menjadi prioritas, hal tersebut dikarenakan urgensi banyaknya kejadian pelanggaran yang terjadi serta pencapaian visi dan misi Kepala Daerah yang telah ditentukan. Keempat perda tersebut adalah : a). Perda Kabupaten Gresik Nomor 22 tahun 2004 tentang Perubahan Perda Nomor 07 tahun 2002 tentang Larangan Pelacur an dan Perbuatan Cabul; b). Perda Kabupaten Gresik Nomor 19 tahun 2004 tentang Perubahan Perda Nomor 15 tahun 2002 tentang Larangan Peredaran Minuman Keras di Kabupaten Gresik; c). Perda Kabupaten Gresik nomor 15 tahun 2013 tentang Penyelenggaraan Trantibum; dan d). Perda Kabupaten Gresik nomor 6 tahun 2017 tentang Izin Mendirikan Bangunan.

\section{B. Metode}

Penelitian ini dilakukan dengan metode penelitian hukum empiris dengan pendekatan sosio legal untuk mengetahui secara deskriptif fungsi Satpol PP dalam penegakan perda di Kabupaten Gresik guna mengkaji efektifitas dan sebagai evaluasi pelaksanaan tugas yang telah dilaksanakan oleh Satpol PP Kabupaten Gresik. Data penelitian didapatkan dari penelaahan peraturan 
perundangan yang mengayomi, observasi terhadap pelaksanaan tugas di lapangan dan wawancara terhadap sejumlah sumber yang dinilai akan memberikan informasi yang diperlukan.. ${ }^{2}$

${ }^{1}$ Muh Hasrul. (2017). "Eksistensi Satuan Polisi Pamong Praja sebagai Penegak Hukum Peraturan Daerah", Jurnal Amanna Gappa, Vol. 25. No. 2 September 2017. h. 62.

${ }^{2}$ Peter Mahmud Marzuki. (2005). Penelitian Hukum. Jakarta: Kencana. h. 93. 


\section{Pembahasan}

\section{Landasan Normatif dan Implementasi Fungsi Satpol PP}

\subsection{Undang-Undang No. 23 Tahun 2014 tentang Pemerintahan Daerah}

Satuan Polisi Pamong Praja dalam Undang-undang 23 Tahun 2014 tentang Pemerintahan Daerah diatur tersendiri dalam Pasal 255 bahwa Satpol PP dibentuk untuk menegakkan Perda dan Perkada, menyelenggarakan ketertiban umum dan ketenteraman, serta menyelenggarakan pelindungan masyarakat. Dalam Pasal selanjutnya, diatur bahwa Satuan Polisi Pamong Praja mempunyai kewenangan:

a. melakukan tindakan penertiban non-yustisial terhadap warga masyarakat, aparatur, atau badan hukum yang melakukan pelanggaran atas Perda dan/atau Perkada;

b. menindak warga masyarakat, aparatur, atau badan hukum yang mengganggu ketertiban umum dan ketenteraman masyarakat;

c. melakukan tindakan penyelidikan terhadap warga masyarakat, aparatur, atau badan hukum yang diduga melakukan pelanggaran atas Perda dan/atau Perkada; dan

d. melakukan tindakan dministratif terhadap warga masyarakat, aparatur, atau badan hukum yang melakukan pelanggaran atas Perda dan/atau Perkada.

\subsection{Peraturan Pemerintah No. 16 Tahun 2018 tentang Satuan Polisi Pamong Praja}

Secara khusus, Satpol PP telah memiliki payung hukum pelaksanaan tugas dan kewenangannya dalam Peraturan Pemerintah No. 16 Tahun 2018 tentang Satuan Polisi Pamong Praja. Peraturan Pemerintah ini merupakan penyempurnaan dari Peraturan sebelumnya dalam PP Nomor 6 Tahun 2010. Dijelaskan dalam pasal 2 (l) Peraturan Pemerintah tersebut, "Untuk menegakkan Perda dan Perkada, menyelenggarakan ketertiban umum dan ketenteraman serta menyelenggarakan pelindungan masyarakat di setiap Provinsi dan Kabupaten/Kota dibentuk Satpol PP”. Sedangkan fungsi yang diemban oleh Satpol PP dijelaskan dalam pasal 6, yakni :

1. Penyusunan program penegakan Perda dan Perkada, penyelenggaraan ketertiban umum dan ketentraman serta penyelenggaraan perlindungan masyarakat

2. Pelaksanaan kebijakan penegakan Perda dan Perkada, penyelenggaraan ketertiban umum dan ketentraman serta penyelenggaraan perlindungan masyarakat 
3. Pelaksanaan koordinasi penegakan Perda dan Perkada, penyelenggaraan perlindungan masyarakat dengan instansi terkait

4. Pengawasan terhadap masyarakat, aparatur atau badan hukum atas pelaksanaan Perda dan Perkada

5. Pelaksanaan fungsi lain berdasarkan tugas yang diberikan oleh Kepala

Daerah sesuai dengan Ketentuan Perundang-undangan.

Kewenangan Satpol PP yang menyertai tugas dan fungsinya dijelaskan dalam pasal 7 Peraturan Pemerintah tersebut, yaitu :

a. melakukan tindakan penertiban non yustisial terhadap warga masyarakat, aparatur, atau badan hukum yang melakukan pelanggaran atas Perda dan/atau Perkada;

b. menindak warga masyarakat, aparatur, atau badan hukum yang mengganggu ketertiban umum dan ketenteraman masyarakat;

c. melakukan tindakan penyelidikan terhadap warga masyarakat, aparatur, atau badan hukum yang diduga melakukan pelanggaran atas Perda dan/ atau Perkada;

d. melakukan tindakan administratif terhadap warga masyarakat, aparatur, atau badan hukum yang melakukan pelanggaran atas Perda dan/atau Perkada

Ketiga pasal di atas merupakan pasal penting sebagai payung hukum yang melindungi pelaksanaan tugas oleh aparat Satpol PP.

\subsection{Permendagri No. 54 Tahun 2011 tentang Standar Operasional Prosedur}

Satpol PP dalam pelaksanaan tugas dan fungsinya seringkali berbenturan dengan masyarakat dan cenderung mendapat opini "perampasan hak asasi manusia". Hal tersebut dikarenakan tugas Satpol PP dalam penegakan aturan baik secara yustisial maupun non yustisial kerap dianggap "merampas" hak-hak para oknum pelanggar Perda dimaksud. Mengantisipasi hal tersebut, dibentuk sebuah Standar Operasional Prosesdur (SOP) yang tertuang dalam Peraturan Menteri Dalam Negeri Nomro 54 Tahun 2011. Standar operasional prosedur tugas Satpol PP dalam pasal 5 disebutkan:

a. Standar Operasional Prosedur penegakan peraturan daerah;

b. Standar Operasional Prosedur ketertiban umum dan ketenteraman masyarakat;

c. Standar Operasional Prosedur pelaksanaan penanganan unjuk rasa dan kerusuhan massa;

d. Standar Operasional Prosedur pelaksanaan pengawalan pejabat/orangorang penting; 
e. Standar Operasional Prosedur pelaksanaan tempat-tempat penting; dan f. Standar

Operasional Prosedur pelaksanaan operasional patroli.

Sedangkan ruang yang melingkupi SOP Satpol PP adalah : a)

Melakukan pengarahan kepada masyarakat dan badan hukum yang melanggar Peraturan daerah b) Melakukan pembinaan dan atau sosialisasi kepada masyarakat dan badan Hukum c) Prefentif non yustisial dan d) Penindakan yustisial. Dalam pelaksanaan tugasnya, Satpol PP wajib untuk

1. Mempunyai landasan hukum

2. Tidak melanggar HAM

3. Dilaksanakan sesuai prosedur

4. Tidak menimbulkan korban/kerugian pada pihak manapun.

\subsection{Peraturan Daerah Kabupaten Gresik}

Sesuai dengan Peraturan daerah nomor 18 tahun 2016 tentang Pembentukan Perangkat Daerah di Kabupaten Gresik, Satpol PP merupakan Perangkat Daerah yang dibentuk untuk 1) Menyelenggarakan ketertiban umum dan ketentraman masyarakat, 2) Penegakan Peraturan daerah dan 3) Perlindungan masyarakat. Sampai dengan tahun 2017, kurang lebih terdapat 69 (enam puluh sembilan) perda bersanksi pidana dan administrasi yang menjadi tanggung jawab dari Satpol PP dalam penegakannya. Dari sekian banyak Perda di Kabupaten Gresik, beberapa Perda yang menjadi prioritas Satpol PP Kabupaten Gresik untuk dilaksanakannya penegakannya antara lain:

a. Peraturan Daerah Kabupaten Gresik Nomor 22 Tahun 2004 tentang Perubahan Perda Kabupaten Gresik Nomor 07 Tahun 2002 tentang Larangan Pelacuran dan Perbuatan Cabul.

b. Peraturan Daerah Kabupaten Gresik Nomor 19 Tahun 2004 tentang

Perubahan Perda Kabupaten Gresik Nomor 15 Tahun 2002 tentang

Larangan Peredaran Miras.

c. Peraturan Daerah Kabupaten Gresik Nomor 15 Tahun 2013 tentang

Ketentraman dan Ketertiban.

d. Peraturan Daerah Kabupaten Gresik Nomor 6 Tahun 2017 tentang Izin

Mendirikan Bangunan.

Penegakan perda oleh petugas Satpol PP dilakukan dengan tujuan perlindungan kepada masyarakat, terciptanya kondusifitas kegiatan

pemerintah dan kemasyarakatan serta untuk meningkatkan pendapatan asli

daerah (PAD). Penegakan perda dimaksud dilaksanakan penegakan dengan mekanisme Deteksi Dini, Preventif, Persuasif, dan Represif sesuai langkah- langkah dalam SOP Satpol PP sebagaimana 
dalam Peraturan Bupati Gresik nomor 26 tahun 2013 tentang Standar Operasional Prosedur Satpol PP.

Fungsi Penegakan Perda yang dilaksanakan oleh Satpol PP sebagaimana telah disebutkan dalam Permendagri Nomor 54 tahun 2011 tentang Standar Operasional Prosedur Satuan Polisi Pamong Praja terdiri dari ruang lingkup :

a. Melakukan pengarahan dan pembinaan kepada masyarakat dan badan hukum yang melanggar Peraturan daerah

b. Penertiban Non Yustisial. Penertiban non yustisial merupakan penertiban yang dilakukan tanpa melalui putusan sidang atau proses

penetapan sanksi oleh Pengadilan. Tahapnnya adalah :

1. Penindakan terhadap para pelanggar Peraturan Daerah, terlebih dahulu menanda tangani surat pernyataan bersedia dan sanggup mentaati dan mematuhi serta melaksanakan ketentuan dalam waktu

15 hari terhitung sejak penandatanganan surat pernyataan.

2. Apabila tidak melaksanakan dan atau mengingkari syarat pernyataannya, maka akan diberikan :

a. Surat teguran pertama, dengan tegang waktu 7 (tujuh) hari

b. Surat teguran kedua, dengan tegang waktu 3 (tiga) hari c. Surat teguran ketiga, dengan tegang waktu 3 (tiga) hari

3. Apabila tidak melaksanakan dan atau mengingkari surat teguran tersebut, akan dilaporkan kepada Penyidik Pegawai Negeri Sipil

(PPNS) untuk dilakukan proses sesuai peraturan perundang- undangan yang berlaku. Penindakan Yustisial yang berarti segala sesuatu yang berkaitan dengan peradilan atau kehakiman. Yustisi juga bisa diartikan sebagai penegakan hukum. Maka yustisi dapat diartikan sebagai upaya penegakan hukum yang dilakukan oleh penegak hukum dengan menggunakan sistem peradilan oleh Penyidik Pegawai Negeri Sipil (PPNS) yang memiliki kewenangan Kepolisian terbatas sesuai dengan Undang-undang Nomor 8 Tahun 1981. Mekanisme penegakan secara yustisial oleh PPNS di lingkungan Satpol PP dapat dilakukan dalam lingkup acara tindak pidana ringan (tipiring) dengan aturan sanksi 3 (tiga) sampai dengan 6 (enam) bulan kurungan dan denda maksimal Rp. 50.000.000,00 (Lima puluh juta rupiah). Dilakukan secara kontinu dan terus menerus terhadap pelanggar perda yang telah dilakukan penindakan, tujuannya agar tidak terulang pelangaran perda yang sama. 


\section{Implementasi Tugas dan Fungsi Satpol PP dalan Penegakan Perda}

Sesuai dengan Peraturan Daerah Kabupaten Gresik Nomor 18 tahun 2016 tentang Perangkat Daerah, di Kabupaten Gresik telah terbentuk Satuan Polisi Pamong Praja. Dipimpin oleh Kepala Satuan, Satpol PP bertanggung jawab kepada Bupati melalui Sekretaris Daerah. Satpol PP di Kabupaten Gresik bertanggung jawab atas pelaksanaan tugas-tugasnya di 18 (delapan belas) Kecamatan.

Penegakan perda oleh Satpol PP menyasar empat Perda yaitu mengenai Larangan Pelacuran dan Perbuatan Cabul; Larangan Minuman Keras;

Penyelenggaraan Ketentraman dan Ketertiban Umum serta Izin Mendirikan Bangunan dilaksanakan sesuai dengan SOP yang telah ditetapkan pada area- area yang berpotensi terjadi pelanggaran perda. Sebagai hasil dari pelaksanaan penegakan perda nampak dalam tabel 1 berikut ini.

Tabel 1

Rekapitulasi Penegakan Perda Tahun 2018 oleh Satpol PP Kabupaten Gresik

\begin{tabular}{|c|c|c|c|c|}
\hline Tindak Lanjut & \multicolumn{4}{|c|}{ Perda yang ditegakkan } \\
\hline & $\begin{array}{l}\text { Perda } \\
\text { Larangan } \\
\text { Pelacuran dan } \\
\text { Perbuatan } \\
\text { Cabul }\end{array}$ & $\begin{array}{l}\text { Perda } \\
\text { Larangan } \\
\text { Peredaran } \\
\text { Minuman } \\
\text { Keras }\end{array}$ & $\begin{array}{l}\text { Perda } \\
\text { Peyelenggaraan } \\
\text { Trantibum }\end{array}$ & $\begin{array}{l}\text { Perda } \\
\text { Mendirikan } \\
\text { Bangunan }\end{array}$ \\
\hline $\begin{array}{l}\text { Sidang } \\
\text { Tipiring/Yustis }\end{array}$ & & & & \\
\hline Pembinaan & 15 & 23 & 115 & \\
\hline Serah Dinsos & & & & \\
\hline Klarifikasi & & & & 37 \\
\hline $\begin{array}{l}\text { Sanksi } \\
\text { Administrasi }\end{array}$ & & & 370 & 9 \\
\hline Total & 15 & 23 & 485 & 46 \\
\hline
\end{tabular}

Sumber : Bidang Penegakan Perda Satpol PP Kabupaten Gresik.

Menilik tabel 1 tersebut, pelanggaran perda yang paling sering terjadi di Kabupaten Gresik adalah pelanggaran Perda Nomor 15 tahun 2013 tentang Ketentraman dan Ketertiban Umum. Bentuk pelanggaran yang umum terjadi adalah para PKL yang berdagang di area larangan dan keberadaan gelandangan dan pengemis di sekitar Kota. Dari sisi aturan Perdanya, pelanggaran Ketentraman dan ketertiban umum hanya dikenakan sanksi administrasi, yaitu berupa pembinaan dan tindakan administratif tanpa melalui sidang di Pengadilan Negeri, karenanya diindikasi pelanggaran perda masih kerap terjadi. 
Efektif atau tidak sebuah peraturan daerah juga dapat dilihat dari tanggapan masyarakat sebagai penerima hasil pekerjaan yang dilakukan oleh Satuan Polisi Pamong Praja. Stakeholders terbesar pelayanan Satpol PP adalah warga masyarakat, Pemerintah dan OPD terkait dan pihak Legeslatif. Peneliti melakukan obeservasi dan wawancara mendalam terhadap pelaksanaan tugas dan fungsi Satpol PP dalam penegakan peraturan daerah di Kabupaten Gresik. Obeservasi dan wawancara dilakukan di bulan Februari 2019 di tempat-tempat strategis terjadinya pelanggaran perda, yaitu di Pasar Gresik, WEP, Alun-alun dan Bundaran Perumahan GKB Gresik.

Hasil observasi menunjukkan bahwa secara rutin petugas Satpol PP melakukan patroli wilayah, berhenti beberapa saat dan kemudian berkelilingkembali. Ketika berhenti, petugas melakukan peneguran, memindahkan para pelanggar baik PKL maupun warga yang parkir sembarangan, melakukan penertiban reklame serta menegur muda-mudi yang berpacaran di tempat umum. Penertiban tersebut berlangsung lancar, tanpa perlawanan dan tanpa kendala. Para pelanggar berpindah lokasi dan menertibkan sendiri dagangannya ketika ada petugas Satpol PP. Akan tetapi ketika petugas berpindah ke lokasi lain, para pelanggar kembali menempati posisi semula. Sedangkan wawancara dilakukan terhadap 7 (tujuh) orang responden yang diambil secara acak (random purposive sampling) yang terdiri atas warga masyarakat, pejabat terkait, pihak swasta, dan akademisi. Sampel ini dianggap telah mewakili sampel secara luas dari metode untuk melokalisir semua kasus yang mungkin dari suatu populasi dengan spesifikasi yang tinggi dan sulit dijangkau. Wawancara dilakukan untuk mengetahui tanggapan dan harapan masyarakat Kabupaten Gresik terkait kegiatan penegakan perda yang telah dilakukan oleh Satpol PP sepanjang tahun 2017-2018.

Dari hasil wawancara ketujuh sampling tersebut, disebutkan bahwa para responden telah menyatakan hasil positif dari proses penertiban dan penegakan perda yang dilakukan oleh Satpol PP yaitu terwujudnya keindahan, kerapian, ketentraman dan ketertiban di masyarakat dan mendongkrak peningkatan PAD. Akan tetapi ada beberapa hal yang masih belum maksimal, diantaranya adalah penertiban yang tidak membuat jera pelanggar sehingga seperti kucingkucingan antara pelanggar dan petugas, adanya kesan tebang pilih yang dilakukan petugas, kurang meratanya daerah yang ditertibkan, kurang humanis dan hanya melakukan penertiban pada kaum minoritas (PKL).

Seperti kita lihat pula dari tanggapan masyarakat, masih adanya permasalahan yang umum terjadi dalam proses penegakan perda yakni :

a. Belum meratanya proses penegakan perda di seluruh wilayah

Kabupaten Gresik;

b. Masih terulangnya pelanggaran perda; 
c. Sanksi yang kurang membuat efek jera.

Kendala-kendala yang muncul tersebut tentunya akan dievaluasi untuk menjadi perbaikan dan optimalisasi implementasi fungi dan tugas pokok Satpol PP mendatang. Beberapa faktor penghambat, atau kendala dalam upaya penegakan peraturan daerah di Kabupaten Gresik antara lain

1. Terbatas sumber daya yang dimiliki.

2. Kelembagaan yang masih bertipe eselonering II B.

3. Belum maksimalnya kapasitas personil dalam teknis penanganan pelanggaran perda.

4. Sanksi dalam perda yang kurang mengikat dan kurang mengakibatkan efek jera bagi para pelanggar.

5. Adanya oknum yang memback up para pelanggar, sehingga menyulitkan proses penertiban pelanggar perda.

6. Stigma negatif masyarakat terhadap Satpol PP;

7. Masih perlunya dukungan masyarakat luas dalam upaya penegakan perda.

Empat perda yang telah kita ulas mendalam tersebut telah mewakili kegiatan penegakan perda yang telah dilakukan Satpol PP selama ini. Kembali kepada kaidah bahwa perda sebagai hukum atau aturan yang berlaku di masyarakat, Wignjosoebroto" menyatakan bahwa "Hukum itu pada hakikatnya adalah suatu perangkat instrument yang di tangan sebuah institusi kekuasaan akan difungsikan guna mengontrol perilaku warga dalam kehidupan mereka sehari- hari. Seberapa ketat atau longgarnya kontrol itu tidak mengurangi konsep para teoritisi sosial bahwa pada dasarnya hukum itu adalah instrument kontrol, hukum ditengarai sebagai sifatnya yang formal dan politis, tanpa peduli warga itu suka dan rela atau tidak untuk menaatinya.

Efektivitasnya hukum menurut Soerjono Soekamto ${ }^{4}$ disebutkan sebagai berikut :

1. Faktor hukumnya sendiri (undang-undang), dimana undang-undang menciptakan sebuah aturan bagi masyarakat untuk ditaati.

2. Faktor penegak hukum, yakni pihak-pihak yang membentuk maupun yang menerapkan hukum. Hukum akan dinilai efektif bila penegak hukum dapat melakukan penegakan hukum tanpa pandang bulu dan profesional.

3. Faktor sarana atau fasilitas yang mendukung penegakan hukum.

Terkadang kendala penegakan perda adalah kurang tersedianya sarana dan prasarana guna melakukan penegakan perda.

4. Faktor masyarakat, yakni lingkungan dimana hukum tersebut berlaku atau diterapkan. Masyarakat yang mendukung dan memberikan peran serta maksimalnya akan membuat hukum semakin efektif diterapkan 
dalam masyarakat.

5. Faktor kebudayaan, yakni sebagai hasil karya, cipta dan rasa yang didasarkan pada karsa manusia dalam pergaulan hidup.

Terkait adanya kendala yang dirasakan oleh Satpol PP, beberapa langkah yang dapat diambil antara lain :

1. Penguatan Kelembagaan dan Peningkatan Peningkatan Sumber Daya di Satpol PP.

2. Penciptaan Norma Sosial di Masyarakat sebagai Aturan yang Mendukung Implementasi Satpol PP, pengaturan tersebut dapat berbentuk Peraturan Desa (Perdes) yang memuat aturan serupa dengan yang diatur dalam Perda namun sanksi bersifat otonom sesuai dengan karakteristik desa tersebut.

3. Sinergitas peran dan Cross cutting antar Perangkat Daerah.

\footnotetext{
${ }^{3}$ Soetandyo Wignyosoebroto.(2002). Hukum, Paradigma, Metode, dan Masalah ELSAM dan HUMA. Jakarta. h. 24
}

${ }^{4}$ Soerjono Soekanto. 1985. Penelitian Hukum Normatif, Suatu Tinjauan Singkat. Jakarta: Rajawali. h. 45 
4. Pemberdayaan Peran serta masyarakat masyarakat : Kader Penegak Perda yang akan menjadi kader di masyarakat yang dapat melakukan fungsi cegah dan lapor terhadap terjadinya pelanggaran perda di tingkat pertama, yaitu Desa.

5. Koordinasi dengan Aparat Penegak Hukum.

\section{Kesimpulan}

Satpol PP sesuai dengan amanat Undang-Undang Pemerintahan Daerah Nomor 23 tahun 2014 pasal 255 menyelenggarakan fungsi : 1) Penyelenggaraan Ketertiban Umum dan Keterntraman Masyarakat; 2) Penegakan Peraturan Daerah dan 3) Perlindungan Masyarakat. Sedangkan fungsi Satpol PP dalam rangka penegakan peraturan daerah sebagaimana telah diatur dalam Peraturan Menteri Dalam Negeri Nomor 54 Tahun 2011 tentang Standar Operasional Prosedur Satuan Polisi Pamong Praja terdiri atas yang pertama melakukan pengarahan dan pembinaan kepada masyarakat dan badan hukum yang melanggar Peraturan daerah, kedua adalah melakukan penertiban non yustisial. Fungsi ketiganya adalah melakukan penegakan perda secara yustisial dan yang terakhir adalah melakukan pengawasan terhadap para pelanggar. Pelaksanaan tugas penegakan perda oleh Satpol PP di Kabupaten Gresik dilaksankan melalui preemtif, preventif, persuasif dan represisf secara humanis kepada masyarakat tanpa tebang pilih.

Penegakan pelanggaran peraturan daerah di Kabupaten Gresik diprioritaskan pada empat kelompok perda yang dinilai paling banyak pelanggarannya berkaitan dengan pencitraan daerah, yaitu 1). Perda Nomor 22 tahun 2004 tentang Perubahan Perda Nomor 7 tahun 2002 tentang Larangan Pelacuran dan Perbuatan Cabul; 2) Perda Nomor 19 tahun 2004 tentang Perubahan Perda Nomor 15 tahun 2002 tentang Larangan Peredaran Minuman Keras; 3) Perda Nomor 15 tahun 2013 tentang Ketentraman dan Ketertiban Umum; serta 4) Perda Nomor 16 tahun 2017 tentang Izin Mendirikan Bangunan.

Guna optimalisasi pelaksanaan tugas dan fungsi penegakan peraturan daerah, beberapa saran yang dapat diberikan antara lain:

1. Masih perlunya dukungan untuk Satpol PP, baik dari eksekutif dan legeslatif, terkait dengan anggaran, pemenuhan sarana dan prasarana, regulasi dan perlindungan terhadap petugas Satpol PP.

2. Guna optimalisasi fungsi Penegekan Perda, Satpol PP perlu melakukan langkah-langkah sebagai berikut :

a. Peningkatan Sumber Daya di Satpol PP, baik anggaran, sarana prasarana dan sumber daya manusia.

b. Penciptaan Norma Sosial di Masyarakat. 
c. Sinergitas peran dan Cross cutting antar Perangkat Daerah.

d. Pemberdayaan Peran serta masyarakat masyarakat, yaitu dengan membentuk Kader Penegak Perda di masyarakat untuk mempercepat proses cegah - lapor terjadinya pelanggaran perda oleh warga masyarakat.

e. Koordinasi dengan Aparat Penegak Hukum untuk mencegah terjadinya mal administrasi dan perlawanan dari pihak yang ditertibkan.

Diharapkan dengan dilaksanakannya kegiatan penegakan perda sesuai dengan Standar Operasional Prosedur dan diperkuat dengan dukungan dari stakeholder terkait, fungsi penegakan perda oleh Satpol PP Kabupaten Gresik dapat berjalan optimal.

\section{Bibliography}

Muh Hasrul. (2017). "Eksistensi Satuan Polisi Pamong Praja sebagai Penegak Hukum Peraturan Daerah", Jurnal Amanna Gappa, Vol. 25. No. 2 September 2017.

Peter Mahmud Marzuki. (2005). Penelitian Hukum. Jakarta: Kencana. h. 93. Soetandyo

Wignyosoebroto.(2002). Hukum, Paradigma, Metode, dan Masalah. ELSAM dan HUMA. Jakarta.

Soerjono Soekanto. 1985. Penelitian Hukum Normatif, Suatu Tinjauan Singkat. Jakarta: Rajawali. 